\title{
ETV6/JAK2 Fusion Gene
}

National Cancer Institute

\section{Source}

National Cancer Institute. ETV6/JAK2 Fusion Gene. NCI Thesaurus. Code C99416.

A fusion gene that results from a chromosomal translocation $t(9 ; 12)(p 24 ; p 13)$ which fuses the 5' half of the ETV6 gene to the 3' portion of the JAK2 gene. This fusion is associated with acute myeloid and lymphoid leukemias. 